\title{
CHOVÁNÍ ATRAZINU ZA DENITRIFIKAČNÍCH PODMÍNEK
}

\author{
THE BEHAVIOUR OF ATRAZINE UNDER DENITRIFICATION \\ CONDITIONS
}

Kristína Pániková,

"Kristina.Panikova@vutbr.cz

${ }^{1}$ Vysoké učení technické v Brně, Fakulta stavební, Ústav chemie, Žižkova 17, 60200 Brno

\begin{abstract}
Abstrakt
Atrazin patří mezi nejvíce perzistentní pesticidy, má negativní vliv na životní prostředí a lidský organizmus. Tato látka je častým kontaminantem podzemních vod, ve kterých převládají ideální podmínky pro denitrifikační proces.

Pomocí metodiky dlouhodobého testu byl zkoumán atrazin za denitrifikačních podmínek, vliv na samotný proces denitrifikace a jeho transformační chování. Po 28 dnech byl pozorován jako dominantní proces adsorpce na topolové hobliny, 30,6 \%. Byl zjiššn biotický úbytek $9,8 \%$ a při koncentraci $0,1 \mathrm{mg} / 1$ atrazin významně neovlivnil denitrifikační proces. Stimulace dosáhla hodnoty $6,9 \%$.
\end{abstract}

\section{Klíčová slova}

Adsorpce, atrazin, inhibice denitrifikace, podzemní voda

\begin{abstract}
Atrazine is one of the most persistent pesticides. This substance negatively affects the environment and the human body. It is a frequent contaminant of groundwater, in which ideal conditions for the denitrification process prevail.

Using a methodology of long-term testing, atrazine was investigated under denitrification conditions, as well as its transformation behaviour and effect on the denitrification process itself. After 28 days, adsorption on poplar shavings was observed as the dominant process, $30.6 \%$. A biotic loss of $9.8 \%$ was found, and, at a concentration of $0.1 \mathrm{mg} / 1$, atrazine did not significantly affect the denitrification process. Stimulation reached the value of $6.9 \%$.
\end{abstract}

\section{Key words}

Adsorption, atrazine, inhibition of denitrification, groundwater

\section{1 ÚVOD}

Zemědělství je pro přežití člověka životně důležité, avšak populační růst klade stále větší nároky na produkci [1]. Zvyšování nároků na produkci má za následek aplikaci většího množství chemikálií, které mají ochránit plodiny a podpořit jejich růst. Pro zintenzivnění procesů souvisejících se zemědělstvím se ve velké míře používají pesticidní látky $\mathrm{k}$ hubení škůdců nebo plevelů [2], [3]. Časté používání pesticidů může způsobovat vážné environmentální problémy, zejména $\mathrm{z}$ důvodu jejich vysoké akumulace a perzistence [4]. Př́tomnost pesticidů v ekosystémech má nepř́íznivé účinky, které se liší v závislosti na koncentraci kontaminantu, jeho množství a době expozice [5], [3].

Pesticidy se do povrchových a podzemních vod dostávají především průsaky a smyvy ze zemědělských ploch. Kontaminace podzemních vod pesticidy je velmi závažným environmentálním problémem, který představuje riziko pro lidské zdraví [6]. Znečištění v podzemních vodách je trvalé a souvisí s četností aplikace pesticidů a četností dešt'ových srážek, propustností půdy, rychlostí doplňování zvodnělých vrstev a intenzitou postřiků [7]. Vzhledem $\mathrm{k}$ tomu, že se zvyšuje počet kontaminovaných zdrojů pitné vody, je nutné zkoumat chování pesticidních látek a také studovat metody, které umožní odstranění pesticidů z podzemních vod [6]. Předvídání chování pesticidů $\mathrm{v}$ podzemních vodách, kde převládají denitrifikační podmínky, je však složitým vědeckým a praktickým problémem [8]. Výzkumy zabývající se chováním těchto látek v podzemních vodách 
nejsou př́liš časté. Biodegradace pesticidu za denitrifikačních podmínek byla prokázána $\mathrm{v}$ případě atrazinu v studii od Douglass a kol [9].

Triazinové herbicidy tvoři širokou skupinu sloučenin používaných pro kontrolu plevelů. Jsou velmi perzistentní v půdě, vodě, rostlinách a ve zvířatech [8]. Některé triazinové herbicidy, jako atrazin, můžou při překročení minimální alveolární koncentrace způsobit třes, kardiovaskulární poškození, genové mutace a rakovinu [8]. Atrazin je selektivní herbicid pro kontrolu různých širokolistých plevelů a trav [10]. Atrazin se pravidelně vyskytuje v podzemní, pitné a také v mořské vodě, dokonce byl zaznamenán i v ledu v odlehlých oblastech [11].

Tato studie se zabývá chováním atrazinu za denitrifikačních podmínek, biotransformací, adsorpcí a vlivem této látky na denitrifikační proces.

\section{METODIKA}

Byla použita metodika dlouhodobého testování, která byla vyvinuta a optimalizována autorkou [12]. Dlouhodobé ( 28 dní) laboratorní testy byly simulovány ve 2litrových lahvích. Pracovalo se se 3 paralelními vzorky, které se lišily složením kapalného média (Tab. 1).

Tab. 1 Princip testu.

\begin{tabular}{|c|c|c|}
\hline Vzorek & Složení kapalného média & Popis \\
\hline 1 & $\begin{array}{c}\mathrm{KNO}_{3}\left(15 \mathrm{mg} / 1 \mathrm{~N}-\mathrm{NO}_{3}\right), \mathrm{NaHCO}_{3}(0,5 \mathrm{~g} / \mathrm{l}), \\
\operatorname{metanol}(0,1 \mathrm{ml} / \mathrm{l})\end{array}$ & Probíhá denitrifikace. \\
\hline 2 & $\begin{array}{l}\mathrm{KNO}_{3}\left(15 \mathrm{mg} / 1 \mathrm{~N}-\mathrm{NO}_{3}\right), \mathrm{NaHCO}_{3}(0,5 \mathrm{~g} / \mathrm{l}) \\
\quad \text { atrazin }(100 \mu \mathrm{g} / \mathrm{l}) \text { - roztok v metanolu }\end{array}$ & $\begin{array}{l}\text { Probíhá denitrifikace, biodegradace testované } \\
\text { látky a její adsorpce na dřevní štěpku. }\end{array}$ \\
\hline 3 & $\begin{array}{c}\mathrm{KNO}_{3}\left(15 \mathrm{mg} / 1 \mathrm{~N}-\mathrm{NO}_{3}\right), \mathrm{NaHCO}_{3}(0,5 \mathrm{~g} / \mathrm{l}), \\
\text { atrazin }(100 \mu \mathrm{g} / \mathrm{l})-\text { roztok v metanolu, inhibitor } \\
\left(\mathrm{HgCl}_{2} \text { konc. } 6,5 \mathrm{mg} / \mathrm{l}\right)\end{array}$ & $\begin{array}{l}\text { Biologické procesy neprobíhají, probíhá adsorpce } \\
\text { testované látky na dřevní štěpku. }\end{array}$ \\
\hline
\end{tabular}

Do každé lahve se odvážilo 25 g topolových hoblin frakce 1,0-1,5 cm. Bylo přidáno $2000 \mathrm{ml}$ deionizované vody obohacené o $\mathrm{KNO}_{3}$ a $\mathrm{NaHCO}_{3}$. Každý vzorek byl proveden ve 4 opakováních. Obsah každé lahve se probublal argonem, až koncentrace $\mathrm{O}_{2}$ klesla pod $0,5 \mathrm{mg} / 1$. Lahve se následně uzavřely a inkubovaly $\mathrm{v}$ termostatu při $\mathrm{T}=20 \pm 0,5^{\circ} \mathrm{C}$ a bez př́stupu světla.

Po uplynutí 48 hodin se z každé lahve pipetou odebralo $25 \mathrm{ml}$ vzorku, ve kterém se stanovilo $\mathrm{pH}$, koncentrace $\mathrm{N}_{-} \mathrm{NO}_{\mathrm{X}}$ a $\mathrm{O}_{2}$. Poté se lahve rozdělily do tří typů vzorků a byla přidána činidla (Tab. 1). Po smíchání se odebralo $10 \mathrm{ml}$ kapalné fáze ze vzorků 2 a 3 pro stanovení počáteční koncentrace atrazinu. Lahve se uzavřely a inkubovaly při $\mathrm{T}=20 \pm 0,5^{\circ} \mathrm{C}$ ve tmě.

Každých 7 dní byly lahve otevřeny a bylo odebráno $25 \mathrm{ml}$ kapalného média pro stanovení $\mathrm{N}-\mathrm{NO}_{\mathrm{X}}$. Po změření koncentrace $\mathrm{N}-\mathrm{NO}_{\mathrm{X}}$ byla dopočtena potřebná dávka roztoku $\mathrm{KNO}_{3}(10000 \mathrm{mg} / \mathrm{l})$ tak, aby koncentrace dusičnanů byla identická s počáteční hodnotou N-NOX $15 \mathrm{mg} / 1$. Určená dávka roztoku $\mathrm{KNO}_{3}$ se nadávkovala do lahví, které se poté uložily zpátky do termostatu.

Po 28 dnech byl pokus ukončen. Ihned po otevření bylo odebráno $10 \mathrm{ml}$ kapalné fáze ze vzorků 2 a 3 pro analýzu testovaného pesticidu. V lahvích byla stanovena koncentrace $\mathrm{O}_{2}$ a bylo odebráno potřebné množství na analýzu $\mathrm{CHSK}_{\mathrm{Cr}}$. Zbývající vzorek byl přefiltrován přes filtrační papír pro kvalitativní analýzu KA2 a v supernatantu byla změřena koncentrace $\mathrm{N}-\mathrm{NO}_{2}, \mathrm{~N}-\mathrm{NO}_{\mathrm{X}}$ a $\mathrm{pH}$.

Atrazin byl extrahován ze vzorků supernatantu pomocí SPE metody (Solid Phase Extraction). Analýzy koncentrací pesticidů zabezpečovalo Centrum pro výzkum toxických látek v prostředí, RECETOX, metodou kapalinové chromatografie s tandemovou hmotnostní detekcí.

Vliv atrazinu na denitrifikační proces byl hodnocen na základě inhibice denitrifikační rychlosti $\mathrm{r}_{\mathrm{D}}$, která byla vypočtena jako množství odstraněného $\mathrm{N}-\mathrm{NO}_{\mathrm{X}}$ za časovou jednotku. Účinek testované látky byl vyhodnocen na základě rozdílu mezi denitrifikačními rychlostmi vzorků 1 a 2.

Úbytek atrazinu $\mathrm{v}$ důsledku adsorpce byl vyhodnocen $\mathrm{z}$ poklesu jeho koncentrace ve vzorku 3 . Úbytek koncentrace testované látky $\mathrm{v}$ důsledku biodegradace byl hodnocen porovnáním koncentrace ve vzorcích 2 (biotická ztráta + abiotická ztráta) a 3 (abiotická ztráta). 


\section{VÝSLEDKY A DISKUZE}

Denitrifikace je biologický proces, který je ovlivňován řadou faktorů. Vhodný zdroj uhlíku, dostatečná dávka dusičnanů a př́znivé $\mathrm{pH}$ jsou pouze základní faktory.

Pesticidy se v různých př́rodních podmínkách (půda, voda, vzduch) chovají odlišně, záleží zejména na jejich fyzikálních vlastnostech, způsobu aplikace a podmínkách prostředí [8]. Atrazin a jeho metabolity mohou přetrvávat ve vodě a půdě po desetiletí [11]. Proto je při hodnocení výsledků nutno brát v úvahu, že pesticidy jsou velmi stabilní látky a 28 dní je krátká doba na jejich rozklad.

\section{Vliv atrazinu na denitrifikační proces}

Na konci testu byly měřeny vybrané ukazatele, výsledné průměrné hodnoty jsou uvedeny v Tab. 2. Optimální hodnota $\mathrm{pH}$ pro denitrifikační proces je mezi hodnotami 7,0 až 8,0 [13]. Ani u jednoho ze vzorků nebylo zjištěno překročení optima.

Tab. 2 Podmínky na konci testu - průměrné hodnoty ze 4 opakování každého vzorku.

\begin{tabular}{cccccc}
\hline Vzorek & $\mathbf{p H}$ & $\begin{array}{c}\mathbf{O}_{2} \\
\mathbf{m g} / \mathbf{l}\end{array}$ & $\begin{array}{c}\mathbf{N}-\mathbf{N O}_{2} \\
\mathbf{m g} / \mathbf{l}\end{array}$ & $\begin{array}{c}\mathbf{C H S K} \\
\mathbf{m g} / \mathbf{l}\end{array}$ & $\begin{array}{c}\mathbf{r}_{\mathrm{D}} \\
\mathbf{m g} / \mathbf{l} / \mathbf{d}\end{array}$ \\
\hline 1 & - & 2,83 & 0,067 & 120 & 1,10 \\
2 & 7,49 & 1,77 & 0,269 & 220 & 1,18 \\
3 & 7,51 & 4,28 & 0,492 & 260 & 0,02 \\
\hline
\end{tabular}

Po 28 dnech byly naměřené hodnoty $\mathrm{O}_{2}$ vyšší než $0,5 \mathrm{mg} / \mathrm{l}$. Ve vzorku 3 byla naměřena nejvyšší hodnota, a to $4,28 \mathrm{mg} / \mathrm{l}$. Tato hodnota byla očekávána, neprobíhal zde denitrifikační proces. U vzorku 1 a 2 byly hodnoty 2,83 a 1,77 mg/l. Procesu denitrifikace však vyšší hodnoty $\mathrm{O}_{2}$ nevadí, koncentrace rozpuštěného kyslíku je nižší v mikropórech topolových hoblin, ve kterých může denitrifikace probíhat, podobně jako uvnitř vloček aktivovaného kalu [14].

$\mathrm{V}$ průběhu denitrifikace se mohou dusičnany redukovat na dusitany, $\mathrm{N}_{2} \mathrm{O}$ a $\mathrm{NH}_{4}{ }^{+}[15]$. Ani v jednom př́ípadě nedošlo k akumulaci dusitanů, nejvyšší hodnota $\mathrm{N}-\mathrm{NO}_{2}$ byla zjištěna u vzorku 3,0,492 mg/l. U vzorku 2 byla naměřena mírně vyšší hodnota $(0,269 \mathrm{mg} / \mathrm{l})$ než u vzorku 1 . Lze konstatovat, že atrazin nezpůsobuje akumulaci dusitanů.

U všech vzorků byla naměřena $\mathrm{CHSK}_{\mathrm{Cr}}$ nad hodnotou $100 \mathrm{mg} / \mathrm{l}$. Dle Lahdhiri a kol., [16] je toto množství $\mathrm{CHSK}_{\mathrm{Cr}}$ dostatečné pro podporu denitrifikace.

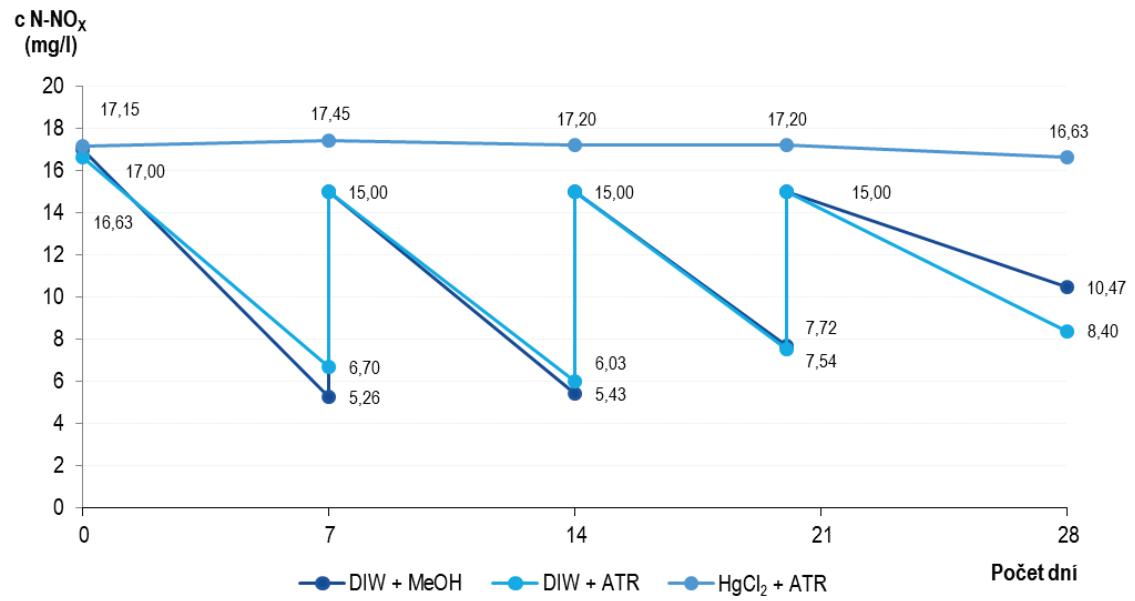

Obr. 1 Koncentrace N-NOX v průběhu testu.

Obr. 1 prezentuje průběh koncentrace N-NOX během testu. U vzorků 1 a 2 probíhala denitrifikace po celou dobu testu i po dodávkování $\mathrm{KNO}_{3}$ každých 7 dní. Proces denitrifikace byl od začátku zastaven u vzorku 3 , nedocházelo tu ke změnám koncentrace. 
Na Obr. 2 je zobrazeno porovnání průměrných denitrifikačních rychlosti jednotlivých vzorků. Denitrifikační rychlost u vzorku 1 a 2 byla porovnatelná. Pouze v posledním týdnu došlo k mírnému zpomalení u vzorku bez př́́davku atrazinu. Ve vzorku 1 byla vypočítaná průměrná rychlost denitrifikace $1,10 \mathrm{mg} / 1 / \mathrm{d}$ a u vzorku 2 hodnota $1,18 \mathrm{mg} / \mathrm{l} / \mathrm{d}$ (Tab. 2). Došlo tedy k mírné stimulaci denitrifikačního procesu atrazinem, konkrétně $6,9 \%$. Ilhan a kol. [17] tvrdí, že rychlost denitrifikace není inhibována koncentracemi atrazinu do $5 \mathrm{mg} / \mathrm{l}$. Tento poznatek koresponduje s výsledky testu, koncentrace $0,1 \mathrm{mg} / 1$ neovlivňuje proces denitrifikace a má mírný stimulační účinek.

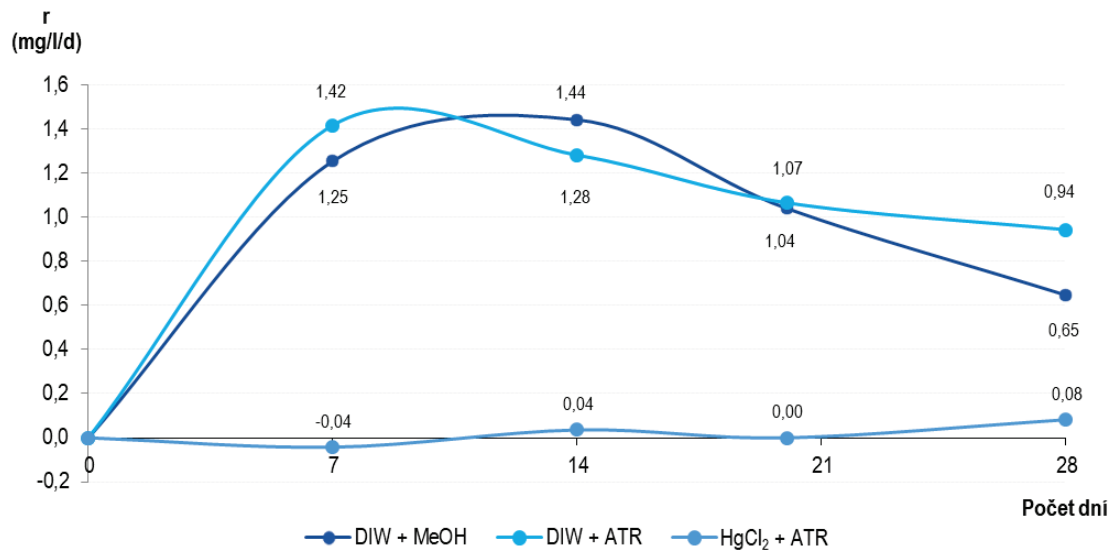

Obr. 2 Průměrné denitrifikační rychlosti v průběhu testu.

\section{Chování atrazinu za denitrifikačních podmínek}

Pesticidy prochází různými transformačními procesy, zahrnujícími jak procesy biotické tak abiotické, které jsou určeny jejich strukturní afinitou ke konkrétnímu typu transformace a podmínkami prostředí, kterým jsou vystaveny v důsledku distribuce a transportního chování [18].

Byl zjištěn abiotický úbytek 30,6 \%. Dle výzkumu Krause Camilo [19] lze předpokládat, že převládajícím mechanismem abiotické ztráty byla sorpce ATR na topolové hobliny. Yue a kol. [20] ve své studii pozorovali adsorpci atrazinu na různé druhy půd. Adsorpce atrazinu byla za 24 hodin přibližně 27,8 \% pro laterit, 21,5\% pro půdu rýžových polí a 19,3 \% u aluviální půdy [20]. Tyto výsledky se shodují s naměřenou hodnotou $(30,6 \%)$.

Biotický úbytek ATR u dlouhodobého testu byl 9,8 \%. To je v souladu s výsledky Douglass a kol. [21], kteří uvádí poločas rozpadu pro ATR 35-40 d. Průměrná hodnota rezidua ATR byla po 28 dnech 59,6 \%.

\section{ZÁVĚR}

Pomocí metodiky dlouhodobého testu bylo pozorováno chování atrazinu o koncentraci 0,1 mg/l za denitrifikačních podmínek. Byl zjištěn biotický úbytek $9,8 \%$ a adsorpce na topolové hobliny dosáhla hodnoty $30,6 \%$. Atrazin významně neovlivňuje denitrifikační proces, byla zjištěna nízká hodnota stimulace a to $6,9 \%$.

V budoucnosti budou pomocí metodiky dlouhodobého testu zkoumány i jiné pesticidní látky, jejich vliv na denitrifikační proces a chování v těchto podmínkách.

\section{Poděkování}

Výzkum byl finančně podpořen v rámci Projektu specifického výzkumu Chování pesticidních látek v průběhu denitrifikace, FAST-J-21-7429. 


\section{Použité zdroje}

[1] SADOWSKI, Arkadiusz a Agnieszka BAER-NAWROCKA. Food and environmental function in world agriculture-Interdependence or competition? Land Use Policy [online]. 2018, 71, 578-583 [cit. 202111-02]. ISSN 02648377. Dostupné z: doi:10.1016/j.landusepol.2017.11.005

[2] ALLETTO, Lionel, Yves COQUET, Pierre BENOIT, Djilali HEDDADJ a Enrique BARRIUSO. Tillage management effects on pesticide fate in soils. A review. Agronomy for Sustainable Development [online]. 2010, 30(2), 367-400 [cit. 2021-11-02]. ISSN 1774-0746. Dostupné z: doi:10.1051/agro/2009018

[3] RICE, Pamela J., Patricia J. RICE, Ellen L. ARTHUR a Aldos C. BAREFOOT. Advances in Pesticide Environmental Fate and Exposure Assessments. Journal of Agricultural and Food Chemistry [online]. 2007, 55(14), 5367-5376 [cit. 2021-11-02]. ISSN 0021-8561. Dostupné z: doi:10.1021/jf063764s

[4] NIE, Jing, Yuqing SUN, Yaoyu ZHOU, et al. Bioremediation of water containing pesticides by microalgae: Mechanisms, methods, and prospects for future research. Science of The Total Environment [online]. 2020, 707 [cit. 2021-11-02]. ISSN 00489697. Dostupné z: doi:10.1016/j.scitotenv.2019.136080

[5] MARGNI, M., D. ROSSIER, P. CRETTAZ a O. JOLLIET. Life cycle impact assessment of pesticides on human health and ecosystems. Agriculture, Ecosystems \& Environment [online]. 2002, 93(1-3), 379392 [cit. 2021-11-02]. ISSN 01678809. Dostupné z: doi:10.1016/S0167-8809(01)00336-X

[6] BARRA CARACCIOLO, Anna, Carmen FAJARDO, Paola GRENNI, Maria Ludovica SACCÃ, Stefano AMALFITANO, Roberto CICCOLI, Margarita MARTIN a Alicia GIBELLO. The role of a groundwater bacterial community in the degradation of the herbicide terbuthylazine. FEMS Microbiology Ecology [online]. 2009, 71(1), 127-136 [cit. 2021-11-02]. ISSN 01686496. Dostupné z: doi:10.1111/j.1574-6941.2009.00787.x

[7] CALDAS, Sergiane S., Adriana DEMOLINER, Fabiane P. COSTA, Marcelo G. M. D'OCA a Ednei G. PRIMEL. Pesticide residue determination in groundwater using solid-phase extraction and highperformance liquid chromatography with diode array detector and liquid chromatography-tandem mass spectrometry. Journal of the Brazilian Chemical Society [online]. 2010, 21(4), 642-650 [cit. 2021-11-02]. ISSN 0103-5053. Dostupné z: doi:10.1590/S0103-50532010000400009

[8] NAVARRO, Simón, Nuria VELA, M JOSÉ GIMÉNEZ a Ginés NAVARRO. Persistence of four striazine herbicides in river, sea and groundwater samples exposed to sunlight and darkness under laboratory conditions. Science of The Total Environment [online]. 2004, 329(1-3), 87-97 [cit. 202111-02]. ISSN 00489697. Dostupné z: doi:10.1016/j.scitotenv.2004.03.013

[9] DOUGLASS, James F., Mark RADOSEVICH \& Olli H. TUOVINEN. Biomineralization of atrazine and analysis of $16 \mathrm{~S}$ rRNA and catabolic genes of atrazine degraders in a former pesticide mixing site and a machinery washing area. Journal of Soils and Sediments. 2016, 16(9), 2263-2274 [cit. 2021-11-02]. ISSN 1439-0108. Dostupné z: doi:10.1007/s11368-016-1416-3

[10] ROSTAMI, Saeid, Shaghayegh JAFARI, Zohre MOEINI, et al. Current methods and technologies for degradation of atrazine in contaminated soil and water: A review. Environmental Technology \& Innovation [online]. 2021, 24 [cit. 2021-11-02]. ISSN 23521864. Dostupné z: doi:10.1016/j.eti.2021.102019

[11] JABLONOWSKI, Nicolai David, Andreas SCHÄFFER a Peter BURAUEL. Still present after all these years: persistence plus potential toxicity raise questions about the use of atrazine. Environmental Science and Pollution Research [online]. 2011, 18(2), 328-331 [cit. 2021-11-02]. ISSN 0944-1344. Dostupné z: doi:10.1007/s11356-010-0431-y

[12] PÁNIKOVÁ, Kristína. Optimalizace metodiky pro testování pesticidů. Vodovod.info - vodárenský informační portál [Online], 2021(2). Dostupné z: http://vodovod.info. [2021-09-10].

[13] PITTER, Pavel. Hydrochemie. 5. aktualizované a doplněné vydání. Praha: Vysoká škola chemickotechnologická v Praze, 2015. ISBN 978-80-7080-928-0.

[14] DAIGGER, Glen T., Craig D. ADAMS a Holley Kaempfer STELLER. Diffusion of Oxygen Through Activated Sludge Flocs: Experimental Measurement, Modeling, and Implications for Simultaneous Nitrification and Denitrification. Water Environment Research [online]. 2007, 79(4), 375-387 [cit. 2021-11-02]. ISSN 10614303. Dostupné z: doi:10.2175/106143006X111835

[15] HU, Rongting, Xilai ZHENG, Tianyuan ZHENG, Jia XIN, Huan WANG a Qiguo SUN. Effects of carbon availability in a woody carbon source on its nitrate removal behavior in solid-phase denitrification. Journal of Environmental Management [online]. 2019, 246, 832-839 [cit. 2021-11-02]. ISSN 03014797. Dostupné z: doi:10.1016/j.jenvman.2019.06.057

[16] LAHDHIRI, Ameni, Geoffroy LESAGE, Ahmed HANNACHI a Marc HERAN. Minimum COD needs for denitrification: from biological models to experimental set-up. DESALINATION AND WATER TREATMENT [online]. 2017, 61, 326-334 [cit. 2021-11-02]. Dostupné z: 
doi:10.5004/dwt.2017.11130

[17] ILHAN, Z. E., S. K. ONG a T. B. MOORMAN. Dissipation of Atrazine, Enrofloxacin, and Sulfamethazine in Wood Chip Bioreactors and Impact on Denitrification. Journal of Environmental Quality [online]. 2011, 40(6), 1816-1823 [cit. 2021-11-02]. ISSN 00472425. Dostupné z: doi:10.2134/jeq2011.0082

[18] FENNER, K., S. CANONICA, L. P. WACKETT a M. ELSNER. Evaluating Pesticide Degradation in the Environment: Blind Spots and Emerging Opportunities. Science [online]. 2013, 341(6147), 752-758 [cit. 2021-11-02]. ISSN 0036-8075. Dostupné z: doi:10.1126/science.1236281

[19] KRAUSE CAMILO, B. Bioreactor reduces atrazine and nitrate in tile drain waters. Ecological Engineering [online]. 2016, 86, 269-278 [cit. 2021-11-02]. ISSN 09258574. Dostupné z: doi:10.1016/j.ecoleng.2015.09.072

[20] YUE, Lin, ChengJun GE, Dan FENG, Huamei YU, Hui DENG a Bomin FU. Adsorption-desorption behavior of atrazine on agricultural soils in China. Journal of Environmental Sciences [online]. 2017, 57, 180-189 [cit. 2021-11-02]. ISSN 10010742. Dostupné z: doi:10.1016/j.jes.2016.11.002

[21] DOUGLASS, James F., Mark RADOSEVICH a Olli H. TUOVINEN. Mineralization of atrazine in the river water intake and sediments of a constructed flow-through wetland. Ecological Engineering [online]. 2014, 72, 35-39 [cit. 2021-11-02]. ISSN 09258574. Dostupné z:

doi:10.1016/j.ecoleng.2014.08.016 